feet in width. Here again the tracks showed unmistakably how the animal had entered the water and come out on the other side.

It therefore appears that narrow channels of water formed no barrier during the food-getting expeditions of this particular coyote, and it may be that much of the depredations on ducks' nests which have been attributed to racoons because of their fondness for water may in reality be due to coyotes, who may not be so averse to swimming as some persons have believed.

- Harold C. Bryant.

THE FLORIDA SPOTTED SKUNK AS AN ACROBAT

April 13,1919, while engaged in field work for the Biological Survey in Lee County, Florida, I established camp on a small prairie dotted with clumps of palmetto scrub close to an arm of the "Big Cypress" known as Kissimmee Billy Strand-being approximately 25 miles southeast of Immokalee. Shortly before sunset, as I was walking along a cow trail close to a palmetto thicket a Florida spotted skunk (Spilogale ambarvalis) suddenly appeared in the trail, not over 10 or 12 feet in front of me, standing erect on his fore legs, with his hind legs spread in a most threatening attitude. I did not see him assume this position, and he maintained it only for an instant, quickly resuming his normal position and disappearing in the brush, leaving only a slight odor behind. Apparently he, as well as I, had been taken by surprise, but just what his purpose was in striking this ludicrous attitude I am unable to say. My guide, Mr. J. M. Youmans, who has hunted extensively in this region, told me he has occasionally seen a similar performance by this skunk. A trap set in the serub resulted in capturing the little acrobat next morning.

This species is essentially a prairie dweller and was found to be common over a large part of Lee County, probably reaching its southern limit not far from the locality mentioned above. On a previous trip 1 captured a specimen at Arcadia in the mouth of a pocket gopher's burrow after he had entirely devoured a trapped gopher (Geomys tuza). I learned also of the occurrence of the species at Palma Sola, on the Guif coast of Manatee County. On the east coast, the species ranges south (rarely) to Lemon City and Cocoanut Grove.

-Arthur H. Howell.

THE FELIS OCELOT OF HAMILTON SMITH

In his important paper on the nomenclature of the small spotted eats of tropical America (Bull. Amer. Mus. Nat. Hist., vol. 41, pp. 341-419, Oct. 3, 1919), Dr. J. A. Allen has concluded after extensive discussion that if Felis ocelot $\mathrm{H}$. Smith "is taken seriously it can only be construed as a synonym of Felis pardalis Linne." Should there be any doubt as to the correctness of this opinion, it may be noted that Smith's name is preoccupied by Felis ocelot Link, 1795 (Beytr. Zool., 2, p. 90), which is an undoubted synonym of Felis pardalis Linnæus.

Hamilton Snith described four varieties of his Felis ocelot, respectively numbered 1, 2, 3, and 4. Of these, No. 4 was identified with Felis pardalis Linneus by Griffith in 1827 and has not been named subsequently; No. 1 was named Felis chibigouazou also by Griffith in 1827 ; No. 2 was called Felis hamiltoni, and no. 3 
Felis griffthii, both by Fischer in 1830 . Variety No. 2 was renamed smithii and No. 3 canescens by Swainson in 1838 (Anim. in Menag., pp. 120-121). Smith expressed the opinion, unsupported by any direct evidence, that Nos. 1 and 2 were South American and Nos. 3 and 4 Mexican. The names based on them have been allocated largely on the strength of this statement as to localities for the descriptions and figures offer little in the determination of forms known to be variable and at best only subspecifically separable. Thus Allen has regarded the two names based on Nos. 1 and 2 as South American and synonymous, recognizing chibigouazou, the earlier one, and placing hamiltoni as a synonym of it. In dealing with the Mexican ones, however, he has recognized two forms (griffithii and pardalis) representing Smith's Nos. 3 and 4 . In this he was doubtless influenced by the grayish color aseribed to Smith's specimen of No. 3. In view of the great variability in the group, as fully noted by Allen, and in consideration of the nature of the ease, which is not one of distinct species but of intergrading subspecies of which even actual specimens may be difficult to determine, it would seem desirable to place griffithii as a synonym of pardalis on much the same grounds that hamiltoni is placed under chibigouazou. By so doing, albescens, which is already well established for the form of northeastern Mexico and the south-central United States, would be retained.

Even the recognition of chibigouazou seems open to question, for at least two earlier names of possible pertinency are to be considered. These are Felis maraqua Link, 1795 (Beytr. Zool., 2, p. 91) and Lynx brasiliensis Oken, 1816 (Lehrb. Naturg., Zool., 3, p. 1050). The first is described as follows: "F. maraqua, cauda elongata, corpore Iuteo, dorso nigro striato, lateribus nigro-maculatis." The word maraqua, used by Link as a specific name, seems to be a variant of one of the Brazilian names for cats of the pardalis group; therefore, it carries the implication that the description was derived from some previous account of one of these animals. However, the source of the name is not indicated otherwise and the description itself is so brief and so generalized that it might apply to any of several species. Like many other names, it is not wholly unidentifiable, for at least it refers to a South American spotted cat. It may therefore, be synonymized with any definitely identifiable earlier name for such a cat, as for example, Felis tigrina Schreber, 1777. To attempt to establish it in use would only be justified in case it was the earliest name applied to any cat having the characters mentioned.

Turning to Oken's name Lynx brasiliensis, we find a description of considerable detail with measurements and association with the native name mbaracaya. Although the source of this native name is not cited by Oken, the large use which he has made of Azara's work on the quadrupeds of Paraguay in other cases makes it probable that the name was obtained from that work. The probability is greatly strengthened by comparison of Oken's description and Azara's text which show numerous points of similarity. There is nothing in Oken's description which cannot be found in Azara except the measurement of total length, given as 22 inches, an obvious error, probably a misprint for 42 inches, the dimension given by Azara. The tail length of 13 inches is given by both authors. The evidence is thus convincing that Oken's brasiliensis was based on Azara, who states definitely (Quad. Paraguay, 1, p. 152, 1801) that the mbaracaya is the same as the chibigouazou. Hence the technical name chibigonazou should be supplanted by brasiliensis. 
From the foregoing, therefore, it is concluded (1) that Felis ocelot Sraith is preoccupied and wholly untenable, (2) that Felis griffithit Fischer is a synonym of Felis pardalis Linnaeus, (3) that Felis maraqua Link is not fuliy identifiable and may be disposed as a possible synonym of Felis tigrina Schreber, and (4) that Felis chibigouazou Griffith is a synonym of Lynx brasiliensis Oken which becomes Felis (Leopardus) pardalis brasiliensis, the first tenable name for a South American cat of the pardalis group. Thus not only the troublesome Felis ocelot goes out of use, but also all the names based on the so-called varieties associated with it by Hamilton Smith. -Wilfred H. Osgood.

\section{NOTE ON GUELDENSTAEDT'S NAMES OF CERTAIN SPECIES OF FELIDA}

Recent investigations of the African Felidx have led me to the consideration of the nomenclature of the caracal group, and especially to the alleged "Felis caracal Gueldenstaedt."' Although Gueldenstaedt's names were given correct binomial form by nearly all subsequent authors they are not binomial in Gueldenstaedt's text. The first author known to me to have challenged their acceptance is Matschie, in a paper on the caracals published in $1912,{ }^{2}$ in which he states that Gueldenstaedt's names cannot be accepted because they are none of them binomial. To demonstrate the correctness of Matschie's claim it is only necessary to quote Gueldenstaedt's diagnoses, which run as follows:

"Lynx: Felis auriculis apice barbatis; capite et corpore albido-ruffo, nigro maculato; cauda obsolete annulata, apice nigra;

"Felis ruffa: Felis auriculis apice barbatis; capite ruffo, fronte et temporibus nigro striatus; corpore ruffo, fusco maculato; cauda subtus et apice alba, supra nigro fasciata;

"Caracal: Felis auriculis apice barbatis, extus nigris; capite, corpore et cauda unicoloribus fuscentibrunneis;

"Chaus: Felis auriculis apice nigro barbatis, extus brunneis; capite, corpore et caudæ basi unicoloribus, fuscenti-luteis; cauda apicem versus albido et nigro annulata, ipso apice nigro."

The second of these species, "Felis ruffa," has the appearance of being binomially named, but a reference to the preceding context on the same page (page 499, second paragraph") is sufficient to show that this is, as well as "Lynx," "Caracal," and "Chaus," a vernacular name, not a technical one, it being simply the rufous cat; in other words, the "Bay cat" of Pennant translated into Latin, the language in which Gueldenstaedt's paper is written. In other parts of his

' Chaus, animal deli affine descriptum. Auctore A. I. Gueldenstaedt. Novi Comm. Acad. sci. imp. Petropolitana, XX (for 1775), 1776, pp. 483-500, pls. xiv, xv, animal and skull of the Chaus. Diagnoses of four species, pp. 499-500.

2 Uber einige Rassen des Steppenluchses Felis (Caracal) caracal (St. Müller). Von Paul Matschie. Sitzungsb. Ges. naturf. Freunde Berlin, 1912, pp. 55-67. Comment on Gueldenstaedt's names, pp. 56-57.

3 "A Fele ruffa facile distinguitur," ete.

" Addidit nuper Zoologus his acutissimus (vid. sp. 136. in Synops. of Quadrup.) animal americanum Lynci proximum, quod illi Felis ruffa (bay cat) dicitur. Addamus nune alterum animal asiaticum Caracali adeo cognatum, ac Felis ruffa Lynci, quod a nobis Chaus appelator." (Op. cit., p. 484.) 